\title{
Analysis of student satisfaction regarding the use of online technologies and resources in Forensic Dentistry
}

\author{
Alice Aquino Zanin*; Raíssa Ananda Paim Strapasson*; Rodolfo Francisco Haltenhoff Melani** \\ * MSc, Department of Community Dentistry, School of Dentistry, \\ Universidade de São Paulo \\ ** PhD, Department of Community Dentistry, School of Dentistry, \\ Universidade de São Paulo
}

Received Feb. 16, 2018. Approved Dec. 6, 2018.

\begin{abstract}
This study aimed to assess the level of satisfaction and the learning effectiveness evaluated by undergraduate students after using the virtual environment and its didactic materials offered by the Discipline of Forensic Dentistry, School of Dentistry, University of São Paulo. A case study was carried out with 113 participants, through a semi-structured online questionnaire and Moodle report for data collection. A simple descriptive analysis of the quantitative data and a content analysis of the qualitative data were performed, with subsequent triangulation and correlation of the results. The most accessed didactic materials were activities such as review questions and case studies $(\mathrm{n}=1309)$, followed by workbooks $(n=230)$ and videos $(n=122)$. The activities of the virtual learning environment (VLE) helped students associate theory and practice (89\%), achieve content fixation and identify occasional learning difficulties (93\%). Ninety-eight percent of the students responded that the workbooks had a clear and interactive language, thus promoting autonomy and the ability to learn. Eighty-nine percent of the students agreed that the videos were satisfactory regarding quality and usefulness for learning. The comments made in response to the open-ended question corroborate these figures. The students considered the VLE useful for learning, motivating, accessible and organized, and allowing users freedom of access.
\end{abstract}

Descriptors: Dental Education. Educational Technology. Forensic Dentistry. Teaching Materials. 


\section{INTRODUCTION}

The incorporation of information technologies in education can be considered a facilitating and effective tool for transmitting knowledge to students. The internet has been used effectively in education through the use of virtual learning environments (VLE). Free virtual learning software often includes the Moodle (Modular Object-Oriented Dynamic Learning Environment), which has an open license and takes advantage of the internet without dismissing teachers, thus integrating online with face-to-face activities and seeking to improve the reflection process in educational communities $^{1,2}$.

The VLE is used to make the material used in the classroom available to students, so that they can access it wherever and whenever they wish. Also, it is possible to consult web pages indicated by teachers and procedure manuals for following up laboratory work, check lesson plans, watch videos, answer review questions, conduct case studies, and participate in forums, chat rooms, and other online activities ${ }^{1,3}$.

The combination of web-based with traditional classroom instruction is called blended learning (BL). It is not just about combining information technology with face-toface teaching to increase the means of access to learning or delivering old content in a novel communication medium. BL proposes rethinking and redesigning the teaching-learning relationship by designing, developing and delivering high-quality content to facilitate critical thinking ${ }^{4}$ and build more accurate mental models ${ }^{5}$.

Preparing the digital didactic material and building the teaching and classroom plans must be guided by the pedagogical and technical principles of the course and by the profile of the teachers and students who will work together. Digital learning materials are considered as any resources that aid in the learning process - such as workbooks, games, and videos - and are available in digital media. The diversity of materials made available allows a greater approximation with the different realities of the students, in addition to providing different ways of interacting with the content ${ }^{6}$. These materials, together with multimedia, use hypertext and hyperlink features that allow random, non-linear navigation. Hyperlinks allow students to access other internet pages related to the subject of study, make different connections and build their own reading paths, freeing them from the linearity of the recommended text ${ }^{7}$.

The use of new technological tools has changed the way people think and work. New forms of communication and the ability to manage information pose a challenge to the cognitive abilities of students and to the traditional paradigm of the classroom ${ }^{4}$. It is up to universities to be aware of the technological developments and associate them to student needs in order to discover their transforming potential ${ }^{8}$.

Understanding the students who live in this new reality, their needs and particularities, within a socioeconomic and cultural context, thus serving them appropriately and effectively, is a great challenge faced by the contemporary school $^{9}$. It is equally important to carry out a course review through evaluations concomitantly with its delivery, whenever possible - to adjust to the unsatisfactory points presented by the students, and develop an etechnology plan, as well as allocate current and future funds ${ }^{10}$.

The application of technology has produced a considerable cultural and social impact on work, leisure, and education; therefore, it is fundamental to understand the students living in this context, so that the tools used in the course can be adapted to their needs. 
Several studies have reported the use of technology, particularly of the VLE, in the teaching of several disciplines of dentistry ${ }^{1,3,5,11-}$ 13. However, few studies refer to the use of technology in the teaching of forensic dentistry ${ }^{12}$. Overall research results indicate that students respond positively to web-based education ${ }^{3,11-13}$, and display improved learning ${ }^{11,13}$.

The present case study aims at investigating the satisfaction and learning effectiveness evaluated by undergraduate students after using the virtual environment and its didactic materials offered by the Discipline of Forensic Dentistry, School of Dentistry, University of São Paulo.

\section{METHODS}

This case study ${ }^{14}$ was approved by the Research Ethics Committee of University of São Paulo, Opinion no. 1.366.049. In all, 113 undergraduate students from the School of Dentistry, University of São Paulo, enrolled in the full-time and part-time (night) programs $\left(8^{\text {th }}\right.$ and $10^{\text {th }}$ semesters, respectively), signed a free and informed consent form, accepting to participate in the research. The discipline was given between February and June of 2016.

The teaching of the discipline was carried out in two ways: face-to-face and online. The face-to-face classes were divided into two sessions: expository and laboratorial. On the first day of class, the students were introduced to a learning platform in a session lasting about 30 minutes.

The VLE was developed using the Moodle platform (version 2.6.11), where the learning objects to be used during the semester were introduced. These included didactic workbooks, activities (review questions, games, chatrooms and case studies) and videos, with the aim of providing autonomous and customized study sessions.
Initially, it was thought that all the didactic content of the VLE should be developed with the materials already available on the web; however, it was not possible to find appropriate enough materials with direct and comprehensive information for undergraduate students in the area of Forensic Dentistry. Therefore, it was decided that personalized didactic materials should be developed. All copyright rules were complied with, and all the materials developed used the Creative Commons license (CC-BY$\mathrm{NC}-\mathrm{SA})^{15}$, so that they could be used as an Open Educational Resource ${ }^{16}$.

The didactic workbooks were developed based on a script elaborated from previous studies, whose main points of reference were:

(a) to present the objective of the workbook with clarity and objectivity

(b) to facilitate online reading by using appropriate font size and line spacing ${ }^{17}$;

(c) to make it long enough to provide an overview of the subject, but without exhausting it, thereby encouraging students to search for information on their own ${ }^{18}$;

(d) to use simple, direct and informal language, seeking to engage in a dialogue through the posing of questions ${ }^{17,18}$;

(e) to provide examples and illustrations whenever possible;

(f) to include charts, tables, audios, videos, and video-lessons, animations, among others ${ }^{18}$;

(g) to recommend scientific articles and books for in-depth study of the subject ${ }^{18}$; and

(h) to use hyperlinks and hypertexts ${ }^{17,18}$.

The videos and games were referred to through links, in order to use what was already available on the web, thus saving time and resources. The review questions and case studies were elaborated based on the experience of the teachers and with the purpose of helping students make the connection between theory and practice and were also associated with the skills defined 
for the course $\mathrm{e}^{19}$. At the end of the practical activities, feedback was provided with the appropriate/correct answers to the review questions, which could be answered by the student several times.

In this study, a semi-structured questionnaire with 5 closed questions (table 1) and one open-ended question was used as the data collection method, performed online via the VLE. The closed questions focused on the quality of the learning materials and the activities available online. The Likert scale was used to rate the responses (figure 2). The openended question was "Other observations you may wish to record." The questionnaire was given to students in the last fifteen days of class.

A simple descriptive analysis of the closed questions was performed. No software was used for data analysis of the open-ended question, since the program only manages the data and allows the researcher to find them more quickly, but does not provide a critical analysis. The analysis of the content was performed by two authors, in order to identify the number of themes and group them into categories as follows: (1) pre-analysis and data organization; (2) identification of themes and categories; (3) treatment of results, inference and interpretation ${ }^{20}$. Those data are presented in tables 2 and 3.

The Moodle report, presenting the activities of the course accessed by the students, was also used as a data source. This report was transferred to the MS Excel program and transformed into a chart (figure 1).

Two techniques of data collection (questionnaire and Moodle access report) were used, with qualitative and quantitative data, since the procedure of collecting, analyzing and combining techniques and data interaction in a single research design provides better analytical possibilities. Thus, data and techniques were analyzed through triangulation and correlation of results ${ }^{21}$. It was observed that the results were convergent, with similar inferences, thus confirming both the qualitative data by the quantitative data and the questionnaire by the Moodle report, as demonstrated in the discussion.

\section{RESULTS}

\section{Moodle Report}

Of the 113 students who used the AVA (total 117 students) signed a free and informed consent form, 85 were women and 28, men. Concerning age, 102 students were born between 1979 and 1994, ten were born in 1995, and one, in 1997.

Sixteen workbooks, 6 activities (review questions, case studies and games), and 6 videos were made available on the VLE. According to the Moodle report, the five materials most accessed by students in each category (activities, workbooks, and videos) were selected, and the average number of times accessed were calculated, based on 113 students who used the VLE, as shown in Figure 1.

\section{Online questionnaire}

The online questionnaire was answered anonymously by 97 participants. The statement of closed questions about the didactic materials and the usability of the environment is shown in table 1, and the respective presentation of the percentage of student's satisfaction is in figure 2 .

A total of 26 students replied to the openended question. Only the comments that appeared more than once were considered in the data analysis. The most representative of which are listed in tables 2 and 3 . 


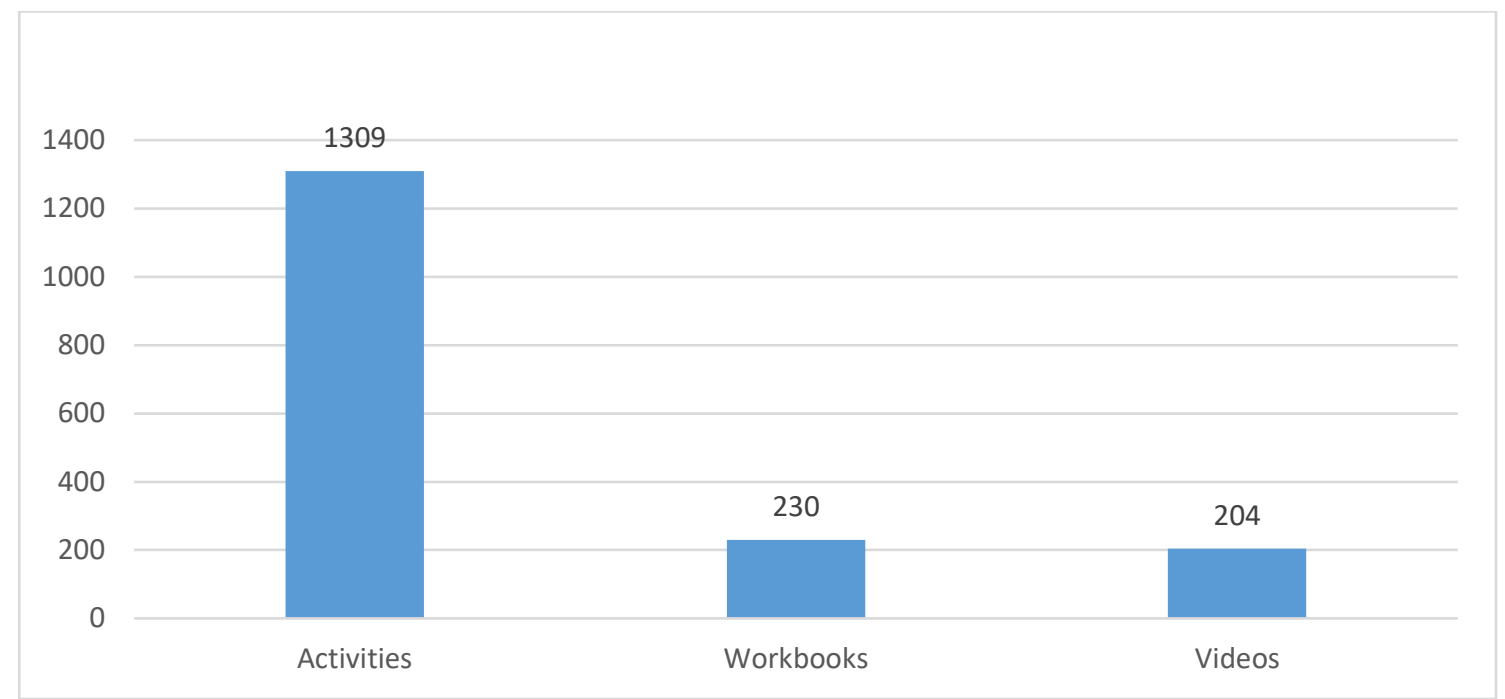

Figure 1. Average views of the five learning objects most accessed in each category, divided into activities, workbooks and videos.

Table 1. Statement of the questions of the online questionnaire concerning the didactic materials and the importance of carrying out activities in the VLE for the learning process.

\section{Statement of questions}

1 The workbooks are structured using clear and interactive language, to promote autonomy and develop your ability to learn.

2 The videos used in the virtual environment were satisfactory regarding quality and were useful in the learning process.

3 The online class used for reading the workbooks on dactyloscopy, rugoscopy and cheiloscopy, and to play the news game, was useful for my learning experience and contributed to gaining a solid understanding of concepts of other subjects.

4 Performing the activities in the virtual environment helped associate theory and practice.

5 Performing the activities in the virtual environment was important for content fixation, identifying occasional learning difficulties and solving them still during the learning process. 


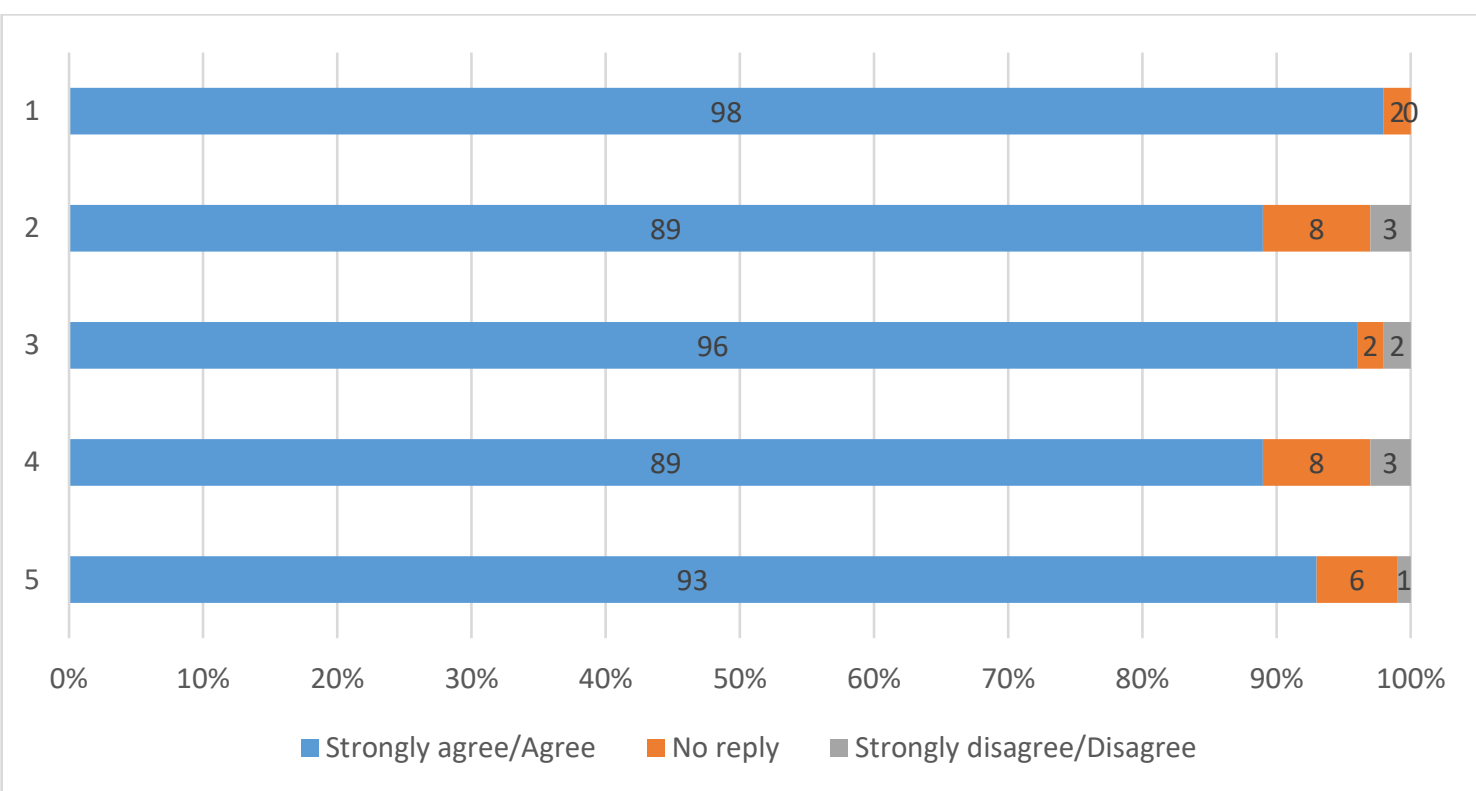

Figure 2. Presentation of the percentage of student satisfaction using the Likert scale, according to the statements presented in table 1.

Table 2. Comments regarding the didactic material category. The identification number of the participant in the database appears in parenthesis.

\section{Themes}

Didactic content

Simple and easy to understand texts

Useful to build knowledge

\section{Examples of comments}

"Although I did all the activities only on the last day before the deadline, I learned a lot from them." The workbooks have a super didactic content. (...) I'm a little disappointed at not having applied myself as much as I should have during the semester, and not having learned even more with this discipline." (7)

"I loved the way the virtual environment was used. The texts are simple and easy to understand and have relevant activities." (9)

"I admit I could have organized myself better to access the Moodle more often, but I managed to do the activities and I realized that the workbooks were/are very useful in building a learning experience." (12) "I really liked the activities carried out in the classroom and in the Moodle; they helped me understand and fix content." (25) "The proposed activities helped me with my learning and helped me put what I learned into practice." (3)

I could pay attention "I really liked this form of organizing the course and the workbooks, since, in class and check later this way, I could pay attention in class, knowing that I would have the workbook with that topic for study in the Moodle." (8) 
Table 3. Comments regarding the virtual learning environment category. The identification number of the participant in the database appears in parenthesis.

\begin{tabular}{ll}
\hline Themes & Examples of comments \\
\hline Motivation & $\begin{array}{l}\text { "It was one of the best disciplines offered, and the virtual environment } \\
\text { helped and motivated me a lot." (17) }\end{array}$ \\
$\begin{array}{l}\text { Usefulness for } \\
\text { learning }\end{array}$ & $\begin{array}{l}\text { "I am in my ninth semester, and, for the first time, found the Moodle really } \\
\text { useful for learning..." (19) }\end{array}$ \\
Accessibility & $\begin{array}{l}\text { "The Moodle platform is generally very accessible, and the activities are } \\
\text { easily understood and very direct..." (18) }\end{array}$ \\
Organization & $\begin{array}{l}\text { "A very organized discipline. In addition, it is concerned with the opinion } \\
\text { of students and always seeks to improve." (6) }\end{array}$ \\
Freedom of access & $\begin{array}{l}\text { "...the discipline surprised me positively, both in regard to the learning } \\
\text { content and the teaching method. (...) the way it is organized (virtual } \\
\text { environment), with content divided into the class subjects, and its } \\
\text { availability until the end of the course, allows the freedom of access } \\
\text { required to complete my studies." (19) }\end{array}$ \\
\hline
\end{tabular}

The results of Moodle report $(n=113)$ and online questionnaire $(n=97)$ were analyzed and correlated, in spite of the divergence of the number of participants because the questionnaire was answered anonymously and it was not possible to individualize the data. However, this factor does not interfere with the research.

\section{DISCUSSION}

Online didactic material is one of the channels of communication and interaction between teacher and student. It must be interactive, dialogical, multimedia and capable of stimulating student autonomy through exploration and self-study ${ }^{6}$. This is why an option was made in the present study to develop didactic workbooks with content appropriate for the needs of undergraduate students. The hyperlinks made available and the readings recommended in the workbooks were designed as channels for the enhancement of dialogue, investigation and exploration by the student ${ }^{7}$.

The role of the teacher, in this case, was that of a facilitator, i.e., to select and group the useful information, because the volume of information currently increases exponentially, making it difficult for the student to select and evaluate what is essential and appropriate ${ }^{8,22}$. All the material was available during the course so that the student could access it and share it at any time. Even after the end of the course, the contents remain available as Open Educational Resources $(\mathrm{OER})^{16}$, so that learning can be continuous throughout the career of the students and anyone who wants to learn. This is important because the modern educational environment requires professionals to continuously develop their skill set by adopting lifelong learning practice.

Ninety-eight percent of the students answered that they agreed or fully agreed with the statement that the workbooks have clear and interactive language, promote autonomy and the ability to learn (table 1, figure 2). The comments made in response to the open-ended question (table 2, lines 2 and 4) reinforce this view. The 
students also said that the workbooks helped resume the content outside the classroom. These comments corroborate McCann's study $(2010)^{10}$, in which students reported that "e-materials," such as workbooks, videos, and podcasts, greatly improved their learning experience.

However, the average number of accesses to the workbooks $(n=230)$ was markedly lower than that of accesses to the activities $(n=1309)$ (figure 1). Handal $(2010)^{3}$, who evaluated students from the same generation as that in the present study, reports that the students requested more activities like quizzes and review questions.

One possible explanation for this phenomenon is that most of the participants of this study (90\%) belong to generation Y, to the Millennials $^{8}$ or to the NeXt generation ${ }^{23}$, which includes individuals born from 1979 to 1994 or from 1982 to 1994 (authors differ regarding dates, depending on the country's level of development $)^{24}$. This generation grew up surrounded by practices related to computers, the internet and cell phones, giving rise to an online social culture with multi-modal messages and meanings, not just in terms of the written word, but also regarding videos, images, and music ${ }^{8}$. For these individuals, doing it is more important than knowing it, and results and actions are more important than the accumulation of knowledge ${ }^{9}$. Other important features are that they prefer to "learn it by doing it," to keep their options open as long as possible, they expect customization features and services with flexibility of time, they multitask, and they enjoy learning through games $^{24}$.

In line with the traits of the students' generation involved in this study, particularly the "learning it by doing it" characteristic, the practical activities available in the VLE were well accepted and widely accessed by students. This preference, already observed in figure 1, was also reflected in these comments: "I really enjoyed the activities performed in the classroom and in the Moodle; they helped me understand and retain the content" (table 2, line 3 ). To the students, performing VLE activities helped associate theory and practice (89\%), was important for content fixation and helped identify occasional learning difficulties (93\%) (table 1, figure 2).

According to Muirhead, Juwah (2004) ${ }^{24}$, access to activities that lead students to reflect on theoretical and practical concepts, to question, dialogue and analyze, are fundamental to hone the quality of the interaction, providing support to the learning experience. The course should present and structure activities that prompt students to reflect within appropriate contexts ${ }^{24}$, and allow them to perceive the relationship between theory and practice ${ }^{6}$. A curriculum based on skills emphasizes problem analysis and problem-solving, and promotes the development of individuals with flexibility, autonomy, and creativity $^{25}$.

Regarding the videos, $89 \%$ of the students agreed that they were satisfactory in quality and useful for learning (table 1, figure 2). Students accessed the videos on average 122 times (figure 1 ), therefore a much lower number of accesses than that of the activities. This result corroborates the study by McCann et al $(2010)^{10}$, in which there was greater access to workbooks $(59 \%)$ than to videos of clinical procedures (54\%) and podcasts (45\%).

In a multi-author review on the use of videos for learning, evidence was found that videos can be a powerful multimodal tool in learning, with increased engagement and achievement by students, and may induce epistemological and social changes among both students and teachers ${ }^{8}$. The presentation of videos (animated or otherwise) can be very enriching because the association of different languages easily reaches young people. 
Furthermore, videos can demonstrate real-world situations, and promote active learning through learner-content interaction ${ }^{11,26}$.

In our study, videos were used in two ways: as a simulation ${ }^{25}$, demonstrating the steps involved in forensic facial reconstruction and DNA analysis; and as an illustration ${ }^{25}$, for example, of facial anatomy and forensic anthropology cases. The video on domestic violence was accompanied by review questions. All the videos available on the VLE were played and watched by the students in the classroom; this may have contributed to their low level of access in the extracurricular environment. As the VLE access was not mandatory, students that chose not to watch the videos could miss the content and be harmed in the final test. Thus, the videos were played and watched in the classroom.

An online asynchronous class was proposed (with a 7-day deadline) as another multimodal content, as a way of diversifying the learning process so that all the students could be reached. It proposed that students read the workbooks, participate in a game freely available on the Internet and answer review questions.

Ninety-six percent of the students considered this strategy useful for learning (table 1 , figure 2). The choice was made to offer a game already available on the web because the development of such a tool requires considerable financial investment, talent, expertise, innovation and resource ${ }^{27}$, factors not available to the team when they developed the VLE.

Although evidence about the effectiveness of games in promoting learning is still incipient, it is known that they have the potential to improve conceptual understanding and produce actionable information that improves teaching and learning, in addition to allowing the learner to "learn it by doing it" 27 . Because games are fun, they also have the potential to motivate learning and arouse the interest and identification of students with the sciences. Another important feature of games is that students are not afraid of making mistakes and can learn from them because they do not constitute a real situation $^{27,28}$.

The environment that combines the use of the web with appropriate multiple media reading, animation, audio, images, video, and hypertext - provides rich, stimulating and interactive learning ${ }^{8}$. This mix of interactive media increases student motivation and can potentially fit the different learning styles, whether visual, auditory, tactile or kinesthetic $^{22,24}$. In the study by Pektas, Gürel $(2014)^{13}$, students noted that access to various resources through the Moodle was very helpful, and requested that more visual materials be included for study and discussion. To this author, the main utility of online tools is to provide access to customized information efficiently.

Students considered the VLE useful for learning and motivating, accessible and organized, and allowing freedom of access, as observed in the comments in Table 3 . This result corroborates the study by Pahinis et al. (2008) ${ }^{11}$, in which $62 \%$ of the respondents believed that the Moodle was easy to navigate, and $75 \%$ considered the online learning environment a useful resource that enhances their skill set.

The use of information and communication technologies (ICT) improves and facilitates learning by reducing the cognitive load, as well as improving content fixation and comprehension. According to Al-Jewair et al $(2010)^{5}$, regardless of whether or not computeraided teaching is more efficient than traditional teaching, what matters most is that the use of technology has advantages, such as better use of time and higher student satisfaction.

The advantages of blended teaching outweigh the challenges that still remain to 
implement this model in universities. It is necessary that higher education institutions overcome budgetary constraints and invest resources in software development, technical support and guidance for teachers on the use of technology in higher education. Teachers must also undertake a critical self-examination and acquaint themselves with the needs of their students, so that important - and sometimes fundamental - changes may be anticipated in the evolution of education before they are preempted by the media, citizen groups, and legislative bodies $^{23}$.

The limitations of this study were related to technological infrastructure, since it was necessary to seek resources from outside our institution to develop the VLE; consequently, it was hard to solve technical problems "on time," because the technicians were external, paid, and not duly committed to the project. This research was conducted with only two classes in one semester; it is advisable to follow up a larger number of classes over the years to ensure continuous improvement of the process, and provide more consistent results and generalizable conclusions.

\section{CONCLUSIONS}

From the analysis of didactic materials available in VLE, the students preferred performing activities ( $n=1309$ accesses), such as case studies, thus preferring the "learning it by doing it" approach, which is a characteristic of Generation Y, the one most represented among the students in this study. Performing the activities in the VLE helped link theory with practice, and was important for content fixation and identification of learning difficulties.

Of the others materials, the workbooks were accessed 230 times in average, and $98 \%$ of the students responded that the workbooks had a clear and interactive language, thus promoting autonomy and the ability to learn. About the videos, eighty-nine percent of the students agreed that they were satisfactory regarding quality and usefulness for learning, having an average of 122 accesses.

The use of technology in education has a positive impact on student satisfaction. Students considered the VLE useful for learning and motivating, accessible, and allowing the user freedom of access. For the students, the activities of the virtual learning environment (VLE) helped them to associate theory and practice $(89 \%)$, and help them to achieve content fixation and to identify occasional learning difficulties (93\%). The initiative of applying technology should not be seen as the ultimate goal but as a step in the continuous process of innovating in education, where the student is its major player.

\section{RESUMO \\ Análise da satisfação discente quanto ao uso de tecnologias e recursos online na Odontologia Forense}

Este estudo teve como objetivo investigar o nível de satisfação e a efetividade de ambiente virtual de aprendizagem e dos materiais didáticos nele disponíveis, experimentados por estudantes de graduação da Faculdade de Odontologia Universidade de São Paulo. Foi realizado um estudo de caso com 113 participantes, em que a coleta de dados ocorreu por meio de grupo focal e questionário online semiestruturado. Foi realizada a análise descritiva simples dos dados quantitativos e a análise de conteúdo dos dados qualitativos, com posterior triangulação e correlação dos resultados. Os materiais didáticos mais acessados foram atividades como questionários e estudos de caso $(n=1309)$, seguidas das apostilas $(n=230)$ e vídeos $(n=122)$. Para os alunos, as atividades do ambiente virtual de aprendizagem (AVA) auxiliaram na associação da teoria com a prática $(89 \%)$, foram importantes para a fixação do conteúdo e auxiliaram na identificação de eventuais dificuldades na aprendizagem (93\%). As 
apostilas possuem linguagem clara e interativa, promovendo autonomia e capacidade de aprender, de acordo com $98 \%$ dos estudantes. Em relação aos vídeos, a concordância de que estes foram satisfatórios quanto à qualidade e úteis na aprendizagem foi de $89 \%$. Os comentários da questão aberta corroboram os números. Os discentes consideraram o AVA útil para o aprendizado, motivador, acessível, organizado e que permite liberdade de acesso ao usuário.

Descritores: Ensino Odontológico. Tecnologia da Educação. Odontologia Forense. Materiais de Ensino.

\section{REFERENCES}

1. Cunha-Araújo IMZ, Salazar-Silva JR, D’Assunção FLC, Melo ABP. Avaliação da percepção dos alunos da disciplina de endodontia sobre o uso do Ambiente Virtual de Aprendizagem (Moodle). Uso do questionário de auto-avaliação COLLES. Rev ABENO. 2013;12(2):163-9.

2. Dougiamas M, Taylor PC. Moodle: using learning communities to create an open source course management system. EDMEDIA 2003 April. National Key Centre for Science and Mathematics Education Curtin University of Technology, Australia 2003. [Cited: 23 Oct. 2016]. Available at: http://research. moodle.net/33/.

3. Handal B, Groenlund C, Gerzina T. Dentistry students' perceptions of learning management systems. Eur J Dent Educ. 2010;14:50-4.

4. Garrison DR, Kanuka H. Blended learning: uncovering its transformative potential in higher education. Internet High Educ. 2004;7:95-105.

5. Al-Jewair TS, Qutub AF, Malkhassian G, Dempster LJ. A systematic review of computerassisted learning in endodontics education. J Dent Educ. 2010;74(6):601-11.

6. Possolli GE, Cury PQ. Reflexões sobre a elaboração de materiais didáticos para educação à distância no Brasil. IX Congresso Nacional de
Educação. 2009 Out 26-29; Paraná, Brasil; p. 3447-62. [Cited: 21 Nov. 2016]. Available at: http://www.pucpr.br/eventos/educere/educere20 09/anais/pdf/2558_1546.pdf.

7. Silva M, Santos E. Conteúdos de aprendizagem na educação on-line: inspirar-se no hipertexto. Educ Ling. 2009 Jan-Jul;12(19):124-42. [Cited: 20 Oct. 2016]. Available at: https://www. metodista.br/revistas/revistasims/index.php/EL/ article/viewFile/817/885.

8. Flood J, Heath SB, Lapp D. Handbook of research on teaching literacy through the communicative and visual arts. London: Taylor \& Francis; 2008. Teacher learning for new times: Repurposing new multimodal literacies and digital-video composing for schools; p. 441-455.

9. Oblinger D. Boomers, gen-xers \& millennial: understanding the new students. EDUCAUSE Review. 2003;38(4):37-47.

10. McCann AL, Schneiderman ED, Hinton RJ. Eteaching and learning preferences of dental and dental hygiene students. J Dental Educ. 2010;74(1):65-78.

11. Pahinis K, Stokes CW, Walsh TF, Tsitrou E, Cannavina G. A blended learning course taught to different groups of learners in a dental school: follow-up evaluation. $\mathrm{J}$ Dent Educ. 2008;72(9):1048-57.

12. Lavez GP, Lino-Jr H, Silva RHA. O uso da teleodontologia no ensino de Odontologia Legal: relato de experiência. Rev ABENO. 2015;15(2):95-104.

13. Pektaş ŞT, Gürel MÖ. Blended learning in design education: an analysis of students' experiences within the disciplinary differences framework. AJET. 2014;30(1):31-44.

14. Yin RK. Estudo de caso: planejamento e métodos. 2nd ed. Grassi D, translator. Porto Alegre: Bookman, 2001. 163 p.

15. Creative Commons [homepage]. [Cited: 7 Dec. 2016]. Available at: https://br.creative commons.org/licencas/. 
16. UNESCO. Declaração REA de Paris em 2012. Congresso mundial sobre recursos educacionais abertos (REA); 2012 Jun 20-22; Paris, France. [Cited: 7 Dec. 2016]. Available at: http://www.unesco.org/new/fileadmin/MULTI MEDIA/HQ/CI/WPFD2009/Portuguese_Declar ation.html.

17. Possari LHV, Neder LMC. Material didático para EaD: processo de produção. Cuiabá: EdUFMT. 2009. 104p. [Cited: 23 Oct. 2016]. Available at: http://www.uab.ufmt.br/uab/ images/livros_download/material_didatico_para _ead_processo_de _producao.pdf.

18. Litto FM, Formiga M. Educação a distância: o estado da arte. 2nd ed. São Paulo: Pearson Education do Brasil; 2012. Livros e apostilas na EAD; p.311-8.

19. Universidade de São Paulo. Faculdade de Odontologia. Projeto Pedagógico do Curso de Odontologia da Faculdade de Odontologia da Universidade de São Paulo. 2013. [Cited: 29 Jan. 2016]. Available at: http://www.fo. usp.br/wpcontent/uploads/Projeto-Pedag \%C3\%B3gicoFOUSP-20141.pdf.

20. Gale NK, Heath G, Cameron E, Rashid S, Redwood S. Using the framework method for the analysis of qualitative data in multi-disciplinary health research. BMC Med Res Methodol. 2013;13:117.

21. Tashakkori A, Teddlie C. Handbook of mixed methods in social and behavioral research. Sage Publications India Pvt. Ltda. 2002. Chapter. A framework for analyzing data in mixed methods research; p. 351-383.

22. Mattheos N, Stefanovic N, Apse P, Attstrom R, Buchanan J, Brown P, et al. Potential of information technology in dental education. Eur J Dent Educ. 2008;12(1):85-91.

23. Sweeney, R. Millennial behaviors \& demographics. 2006; 1-10. [Cited: 1 Jan. 2017]. Available at: https://certi.mst.edu/ $\underline{\text { media/administrative/certi/documents/Article- }}$ Millennial-Behaviors.pdf.

24. Muirhead B, Juwah C. Interactivity in computermediated college and university education: A recent review of the literature. J Educ Techno Soc. 2004 Jan;7(1):12-20.

25. Moran JM. O vídeo na sala de aula. Comunicação \& Educação. 1995 Jan-Abr:27-35. [Cited: 20 Feb. 2017]. Available at: http://www.eca.usp.br/prof/moran/site/textos/de safios_pessoais/vidsal.pdf.

26. Resse DD, Tabachnick BG, Kosko RE. The vision for enhanced teaching and learning through cyberlearning instruction and assessment requires considerable financial, talent, expertise, innovation and resource investment. Br J Educ Technol. 2015: 46(1):98122.

27. National Research Council. Learning science through computer games and simulations. Committee on Science Learning: Computer Games, Simulations, and Education. In M. A. Honey \& M. L. Hilton (Eds), Board on Science Education, Division of Behavioral and Social Sciences and Education. Washington, DC: National Academies Press. 2011. 162p. [Cited: 8 Jan. 2017]. Available at: http://www.nap. edu/catalog.php?record_id=13078.

28. Barko T, Sadler TD. Practicality in virtuality: finding student meaning in video game education. J Sci Educ Technol. 2013;22:124-32.

\section{Correspondence to:}

Alice Zanin

e-mail: alicezanin2@gmail.com Faculdade de Odontologia - FOUSP Departamento de Odontologia Social Av. Prof. Lineu Prestes, 2227 - Butantã 05508-000 São Paulo/SP Brazil 